\title{
Effect of Spark Plug Alteration on Performance Using Hydrogen Enriched Gasoline in Si Engine Under Various Loads and Compression Ratios
}

\author{
Oğuz Baş ${ }^{1 *}$, Mustafa Atakan Akar ${ }^{2}$, Şafak Yıldızhan³ ${ }^{3}$, Mustafa Özcanli ${ }^{4}$, Hasan Serin ${ }^{5}$ \\ Cukurova University, The Faculty of Engineering, Department of Automotive Engineering, Turkey: \\ 'obas@cu.edu.tr, ${ }^{2}$ aakar@cu.edu.tr, ${ }^{3}$ yildizhans@cu.edu.tr, ${ }^{4}$ ozcanli@cu.edu.tr, ${ }^{5}$ hserin@cu.edu.tr \\ ORCID: O.Baş (0000-0003-2301-2306), S.Y.ıldızhan(0000-0002-8981-9869)
}

\begin{abstract}
In this study, change in brake power (BP) of a variable compression spark ignited engine was investigated with different spark plugs and hydrogen enrichment. The tests were carried out with a four stroke, single cylinder, naturally aspirated, variable compression ratio (VCR) engine. Two different compression ratios (CR) of 8.5:1 and 10:1 under \%50 part throttle condition were implemented throughout the experiments. Moreover, engine loads of $8 \mathrm{Nm}, 13 \mathrm{Nm}$ and $17 \mathrm{Nm}$ were applied to evaluate effects of different spark plugs and hydrogen usage at different engine loads. Copper, iridium and platinum spark plugs were tested for each experiment condition. In addition, hydrogen was added through the intake manifold with flow rates of 0,2 and $4 \mathrm{lit} / \mathrm{min}$ to enhance combustion of VCR engine. According to test results, iridium and platinum spark plug usage, hydrogen addition and higher compression ratio improved BP significantly. This variance occurred more obvious with platinum spark plug usage comparing to iridium spark plug. In addition, effects of spark plug alteration, hydrogen addition and higher $\mathrm{CR}$ on enhancement of BP were comparatively lower at higher engine loads.
\end{abstract}

Keywords : Spark plug, hydrogen, platinum, iridium, brake power

\section{INTRODUCTION}

The main energy demand in the world is supplied from the fossil based substances such as petroleum, coal and natural gas. With the development of industry and economy, energy shortage and environmental problems have been becoming more and more serious. The internal combustion engine and automotive industry are confronted with severe and realistic challenges. Gasoline engine is known for their high power to weight ratio, stable and silent performance, low prices, less maintenance needs and costs and feasibilities for CNG and LPG fuels comparing with similar volume of diesel engine. However, their thermal efficiencies and torque outputs are lower comparing with modern diesel engine (Stone and Ball, 2004). These main problems limit the widespread usage of gasoline engines such as heavy duty machineries.

Lean burn is one of the most effective ways to solve the above-mentioned problems. Nevertheless, current engines cannot be run sufficiently lean due to ignition related problems such as the slow flame initiation and propagation along with potential misfiring. In the future of spark ignited engine it is expected that gasoline engines will operate with much higher compression ratios, faster compression rates, and much leaner fuel-to-air ratios for the sake of combustion enhancement and fuel economy. Furthermore it will aggravate the electrode degradation and erosion of the spark plugs more. In order to accomplish these strong challenges, usage of alternative spark plugs is seemed urgent for spark ignited engines.

On the other hand hydrogen is one of the most promising alternative fuel which can be benefited in various ways such as producing electricity for EVs [2]-[5]direct usage [6], [7] or hybrid utilisation [8]-[17] for both spark and compression ignited engines.

\section{MATERIALS AND METHODS}

\subsection{Materials}

Engine tests were conducted on a four stroke, single cylinder, naturally aspirated, water cooled, variable compression engine that can operate with both gasoline and diesel fuel by replacing the engine head. Technical specifications of the 
engine were given in Table 1 . and the engine test rig were shown in Figure 1.

\begin{tabular}{|c|c|}
\hline \multicolumn{2}{|c|}{ Table 1. Technical specifications of the engine } \\
\hline Brand - Model & Kirloskar Oil Engines-240 \\
\hline Configuration & Single Cylinder \\
\hline Type & Four Stroke, \\
\hline Cooling & $661 \mathrm{cc}$ \\
\hline Displacement & $87.5 \mathrm{~mm}$ \\
\hline Bore & $110 \mathrm{~mm}$ \\
\hline Stroke & $1200 / 1800 \mathrm{rpm}$ \\
\hline Minimum / Maximum Operating & \\
\hline Speed & $4.5 \mathrm{Kw} @ 1800 \mathrm{rpm}$ \\
\hline Power & $6: 1-10: 1$ \\
\hline CR range & $0-25^{\circ} \mathrm{BTDC}$ \\
\hline Injection Variation & $77.5 \mathrm{~kg} / \mathrm{cm}^{2}$ \\
\hline Peak Pressure & $160 \mathrm{~kg}$ \\
\hline Weight & Forced Feed System \\
\hline Lubricating System & \\
\hline
\end{tabular}

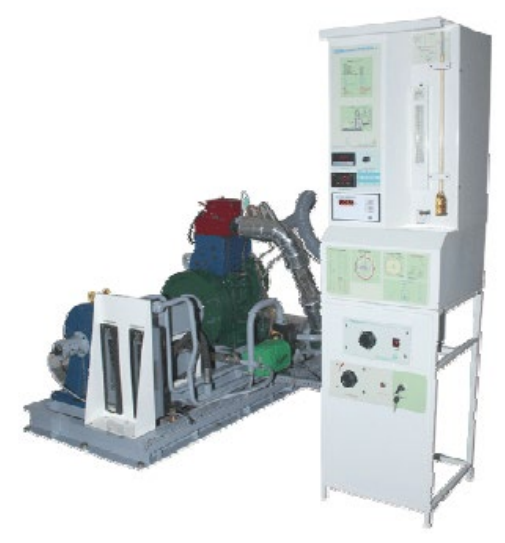

Figure 1.VCR spark ignited engine test rig

\subsection{Methods}

Engine performance measurement experiments were executed with two different compression ratios (8.5:1 and 10:1) under $\% 50$ part throttle condition. During the experiments engine loads of $8 \mathrm{Nm}, 13 \mathrm{Nm}$ and $17 \mathrm{Nm}$ were applied in order to assess effects of spark plugs and hydrogen usage under different engine loads. Copper, iridium and platinum spark plugs were tested respectively for each experiment condition. In addition, hydrogen was blended through the intake manifold with flow rates of $0 \mathrm{lit} / \mathrm{min}$ (H0), $2 \mathrm{lit} / \mathrm{min}$ $(\mathrm{H} 2)$ and $4 \mathrm{lit} / \mathrm{min}(\mathrm{H} 4)$ to enhance combustion of VCR engine.

Before experimental measurements engine was run $5 \mathrm{mi}$ nutes to attain stable operation conditions. "Enginesoft" software was used for logging experimental data. This software logs for 60 seconds when logging starts and at the end of this period gives the average values of experimental data.

As a result of these experiments, brake power (BP) were obtained to evaluate effects of applied methods on performance characteristic of a four stroke, naturally aspirated, water cooled and spark ignited test engine.

\section{RESULTS AND DISCUSSIONS}

Brake power (BP) defined as power output from flywheel or crankshaft of the engine is one of the most critical performance criteria for internal combustion engines. Figure 2-7 shows the brake power output results of the experiments with different compression ratios (8.5:1 and 10:1) and engine loads ( $8 \mathrm{Nm}, 13 \mathrm{Nm}$ and $17 \mathrm{Nm})$.

As can be seen from graphs, usage of iridium and platinum spark plugs improved BP values at all engine loads. However, platinum spark plug enhanced BP more than iridium spark plug. The performance improvement of these spark plugs can be attributed that increased charge density in combustion chamber and enhanced flame propagation. Iridium spark plug usage for hydrogen enriched mixture was resulted with an increment of BP by between 2,27-11,43\% while it was by between $4,76-16,67 \%$ for platinum spark plug. In general, performance enhancement depending on spark plugs and hydrogen enrichment was slightly lower at higher engine loads.

On the other hand, hydrogen induction into the combustion chamber expedited performance improvement, remarkably. Superior chemical and physical properties of hydrogen fuel such as high diffusion and flame speed boosted combustion completeness of the test engine. Nevertheless, as mentioned above, at higher engine loads, performance improvement due to hydrogen injection were less comparing to lower loads. Table 2-3 shows the average variance in BP with hydrogen induction at different engine loads.

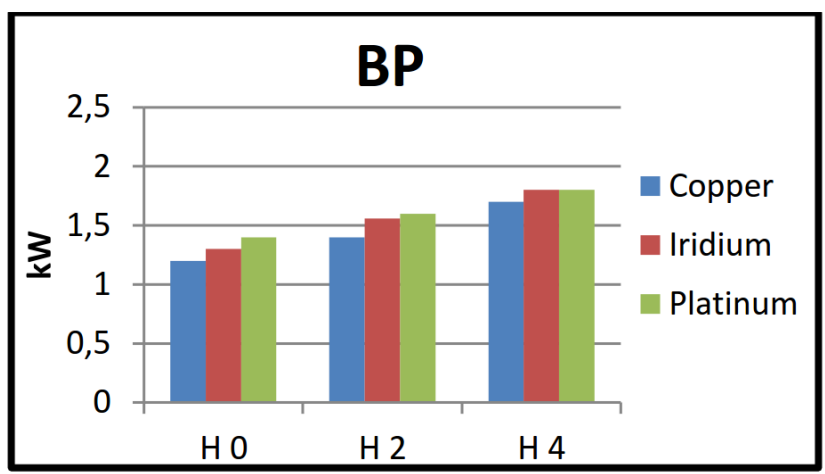

Figure 2. BP values for engine load of $8 \mathrm{Nm}$ and $\mathrm{CR}$ of 8.5:1

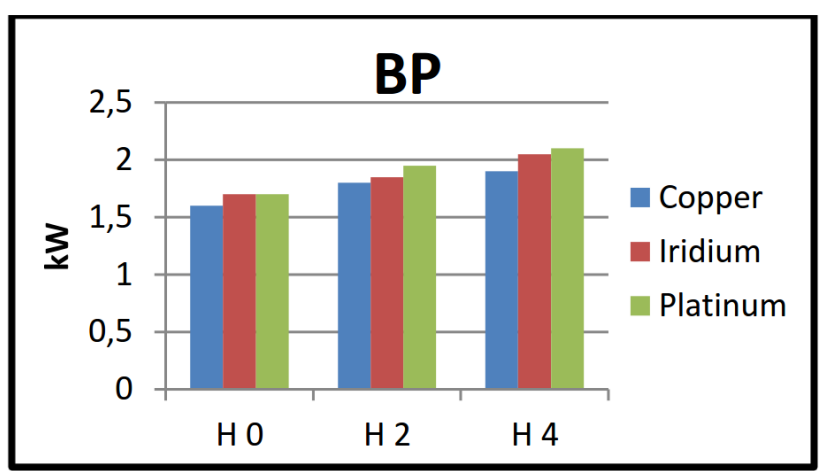

Figure 3. BP values for engine load of $13 \mathrm{Nm}$ and $\mathrm{CR}$ of $8.5: 1$ 
Table 2. Average variance in BP with hydrogen induction at different engine loads and 8.5:1 compression ratio

\begin{tabular}{|c|c|c|c|c|c|c|c|}
\hline & \multicolumn{3}{|c|}{ Copper } & \multicolumn{2}{c|}{ Iridium } & \multicolumn{2}{c|}{ Platinum } \\
\hline \multirow{3}{*}{$\mathrm{BP}$} & & $\mathrm{H} 0-\mathrm{H} 2$ & $\mathrm{H} 0-\mathrm{H} 4$ & $\mathrm{H} 0-\mathrm{H} 2$ & $\mathrm{H} 0-\mathrm{H} 4$ & $\mathrm{H} 0-\mathrm{H} 2$ & $\mathrm{H} 0-\mathrm{H} 4$ \\
\cline { 2 - 8 } & $13 \mathrm{Nm}$ & $17 \%$ & $42 \%$ & $20 \%$ & $38 \%$ & $14 \%$ & $29 \%$ \\
\hline & $17 \%$ & $19 \%$ & $9 \%$ & $21 \%$ & $15 \%$ & $24 \%$ \\
\hline & $17 \mathrm{Nm}$ & $14 \%$ & $26 \%$ & $11 \%$ & $22 \%$ & $11 \%$ & $19 \%$ \\
\hline
\end{tabular}

Table 3. Average variance in BP with hydrogen induction at different engine loads and 10:1 compression ratio

\begin{tabular}{|c|c|c|c|c|c|c|c|}
\hline & & \multicolumn{2}{|c|}{ Copper } & \multicolumn{2}{c|}{ Iridium } & \multicolumn{2}{c|}{ Platinum } \\
\hline \multirow{3}{*}{$\mathrm{BP}$} & & $\mathrm{H} 0-\mathrm{H} 2$ & $\mathrm{H} 0-\mathrm{H} 4$ & $\mathrm{H} 0-\mathrm{H} 2$ & $\mathrm{H} 0-\mathrm{H} 4$ & $\mathrm{H} 0-\mathrm{H} 2$ & $\mathrm{H} 0-\mathrm{H} 4$ \\
\cline { 2 - 8 } & $14 \%$ & $27 \%$ & $14 \%$ & $23 \%$ & $15 \%$ & $22 \%$ \\
\cline { 2 - 8 } & $13 \mathrm{Nm}$ & $11 \%$ & $18 \%$ & $6 \%$ & $12 \%$ & $8 \%$ & $12 \%$ \\
\cline { 2 - 8 } & $17 \mathrm{Nm}$ & $8 \%$ & $15 \%$ & $7 \%$ & $14 \%$ & $8 \%$ & $13 \%$ \\
\hline
\end{tabular}

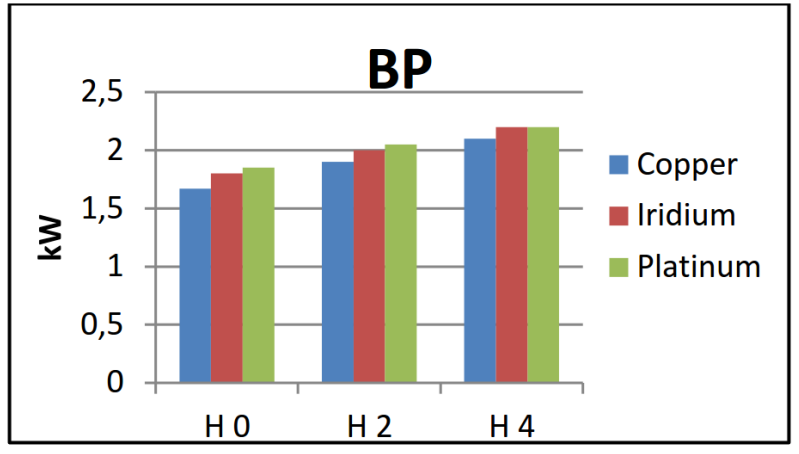

Figure 4. BP values for engine load of $17 \mathrm{Nm}$ and $\mathrm{CR}$ of 8.5:1

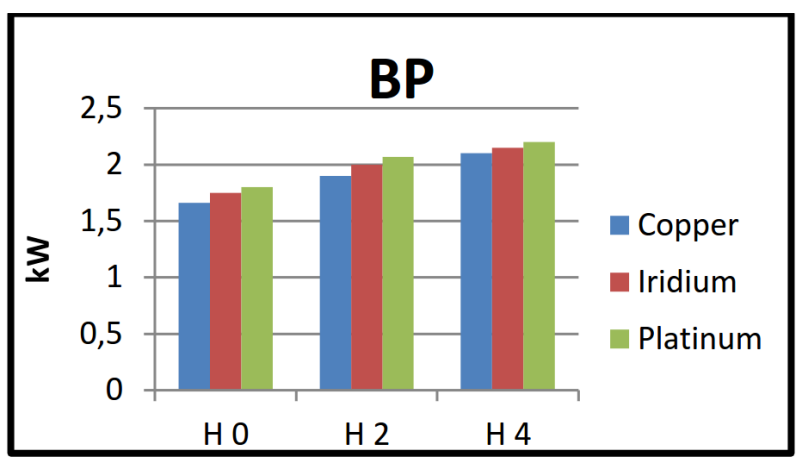

Figure 5. BP values for engine load of $8 \mathrm{Nm}$ and $\mathrm{CR}$ of 10:1

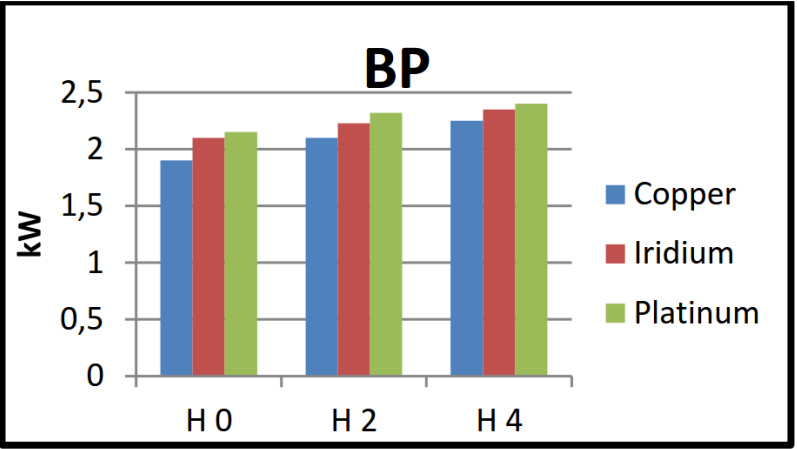

Figure 6. BP values for engine load of $13 \mathrm{Nm}$ and $\mathrm{CR}$ of 10:1

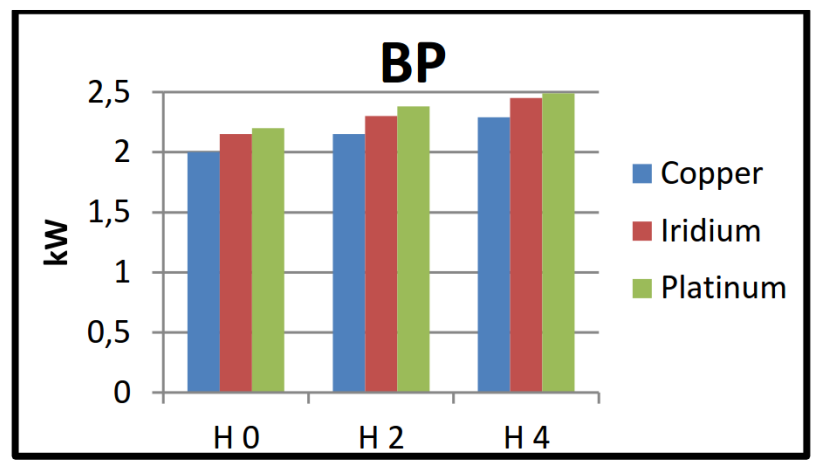

Figure 7. BP values for engine load of $17 \mathrm{Nm}$ and CR of 10:1

\section{CONCLUSIONS}

In this study the BP characteristic of a spark ignition engine at various compression ratios fuelled with gasoline and hydrogen enriched gasoline fuels. During the experiments the engine compression ratio was set as $8.5: 1$ and 10:1 and copper, platinum and iridium spark plugs performed one by one. Besides, each test condition was executed at different dynamometer loads which are $8 \mathrm{Nm}, 13 \mathrm{Nm}$ and $17 \mathrm{Nm}$. According to experimental results, the followings can be summarized;

- Changing conventional (copper) spark plug with iridium and platinum spark plugs expedited combustion development resulting in enhanced BP at all compression ratios, engine loads and hydrogen flow rates.

- Variations in BP mentioned above were more obvious for platinum spark plug than iridium type.

- Similar to spark plug changing, hydrogen addition increased BP values comparing with unhydrogenated fuels.

- Iridium spark plug usage for hydrogen enriched mixture was resulted with increments of BP by between 2,27-11,43\% while it was by between 4,76$16,67 \%$ for platinum spark plug.

- Increasing the hydrogen flow rate, triggered enhancement in BP depending on hydrogen's combustion accelerator function. 
- Increasing CR improved BP values for all test fuels.

- At higher engine loads, changes in BP depending on higher compression ratio and variation of spark plugs were lower comparing to lower engine loads.

\section{ACKNOWLEDGEMENTS}

The authors thank the Scientific Research Projects Directorate of Cukurova University for supporting the present study (FBA-2018-8692).

\section{REFERENCES}

[1] Stone, R., Ball, J.K., (2004). Automotive Engineering Fundamentals.

[2] DeCicco, J.M., Li, X., (2016). Fuel Cell Vehicles. Reference Module in Earth Systems and Environmental Sciences.

[3] Ahmadi, S., Bathaee, S.M.T., Hosseinpour, A.H., (2018). Improving fuel economy and performance of a fuel-cell hybrid electric vehicle (fuel-cell, battery, and ultra-capacitor) using optimized energy management strategy. Energy Conversion and Management 160: 74-84, Doi: 10.1016/j.enconman.2018.01.020.

[4] Hames, Y., Kaya, K., Baltacioglu, E., Turksoy, A., (2018). Analysis of the control strategies for fuel saving in the hydrogen fuel cell vehicles. International Journal of Hydrogen Energy 43(23): 10810-21, Doi: 10.1016/j.jijhydene.2017.12.150.

[5] Brooks, K.P., Sprik, S.J., Tamburello, D.A., Thornton, M.J., (2018). Design tool for estimating chemical hydrogen storage system characteristics for light-duty fuel cell vehicles. International Journal of Hydrogen Energy 43(18): 8846-58, Doi: 10.1016/j.jijhydene.2018.03.090.

[6] Salanki, P.A., Wallace, J.S., (1996). Evaluation of the Hydrogen-Fueled Rotary Engine for Hybrid Vehicle Applications. SAE Technical Papers, Doi: 10.4271/960232.

[7] Wakayama, N., Morimoto, K., Kashiwagi, A., Saito, T., (2006). Development of Hydrogen Rotary Engine Vehicle. WHEC. 16, 13-16.

[8] Amrouche, F., Erickson, P.A., Varnhagen, S., Park, J.W., (2016). An experimental study of a hydrogen-enriched ethanol fueled Wankel rotary engine at ultra lean and full load conditions. Energy Conversion and Management 123: 174-84, Doi: 10.1016/j.enconman.2016.06.034.

[9] Di lorio, S., Sementa, P., Vaglieco, B.M., (2016). Analysis of combustion of methane and hydrogen-methane blends in small DI SI (direct injection spark ignition) engine using advanced diagnostics. Energy 108: 99-107, Doi: 10.1016/j.energy.2015.09.012.

[10] Fan, B., Pan, J., Yang, W., Zhu, Y., Chen, W., (2016). Effects of hydrogen blending mode on combustion process of a rotary engine fueled with natural gas/hydrogen blends. International Journal of Hydrogen Energy 41(6): 4039-53, Doi: 10.1016/j.ijhydene.2016.01.006.

[11] Wu, H., Yu, X., Du, Y., Ji, X., Niu, R., Sun, Y., et al., (2016). Study on cold start characteristics of dual fuel SI engine with hydrogen direct-injection. Applied Thermal Engineering 100: 829-39, Doi: 10.1016/j. applthermaleng.2016.02.097.

[12] Du, Y., Yu, X., Liu, L., Li, R., Zuo, X., Sun, Y., (2017). Effect of addition of hydrogen and exhaust gas recirculation on characteristics of hydrogen gasoline engine. International Journal of Hydrogen Energy 42(12): 8288-98, Doi: 10.1016/j.ijhydene.2017.02.197.

[13] Du, Y., Yu, X., Wang, J., Wu, H., Dong, W., Gu, J., (2016). Research on combustion and emission characteristics of a lean burn gasoline engine with hydrogen direct-injection. International Journal of Hydrogen Energy 41(4): 3240-8, Doi: 10.1016/j.jijhydene.2015.12.025.
[14] Arat, H.T., Sürer, M.G., (2018). State of art of hydrogen usage as a fuel on aviation. European Mechanical Science, 2(1): 20-30, Doi: 10.26701/ems.364286.

[15] Karagöz, Y., Sandalcı, T., Yüksek, L., Dalkılıç, A.S., (2015). Engine performance and emission effects of diesel burns enriched by hydrogen on different engine loads. International Journal of Hydrogen Energy 40(20): 6702-13, Doi: 10.1016/j.ijhydene.2015.03.141.

[16] Kim, J., Chun, K.M., Song, S., Baek, H.-K., Lee, S.W., (2017). The effects of hydrogen on the combustion, performance and emissions of a turbo gasoline direct-injection engine with exhaust gas recirculation. International Journal of Hydrogen Energy 42(39): 25074-87, Doi: 10.1016/j.jijhydene.2017.08.097.

[17] Su, T., Ji, C., Wang, S., Shi, L., Yang, J., Cong, X., (2017). Investigation on performance of a hydrogen-gasoline rotary engine at part load and lean conditions. Applied Energy, 205: 638-691, Doi: 10.1016/j. apenergy.2017.08.049. 